University of Nebraska - Lincoln

DigitalCommons@University of Nebraska - Lincoln

Faculty Publications: Department of Entomology

Entomology, Department of

July 1983

\title{
Dispersal, Flight, and Diurnal Activity Patterns of Adult Southern Corn Billbugs (Coleoptera: Curculionidae)
}

Robert J. Wright

University of Nebraska-Lincoln, rwright2@unl.edu

J. W. Van Duyn

North Carolina State University

J. R. Bradley Jr.

North Carolina State University

Follow this and additional works at: https://digitalcommons.unl.edu/entomologyfacpub

Part of the Entomology Commons

Wright, Robert J.; Van Duyn, J. W.; and Bradley, J. R. Jr., "Dispersal, Flight, and Diurnal Activity Patterns of Adult Southern Corn Billbugs (Coleoptera: Curculionidae)" (1983). Faculty Publications: Department of Entomology. 94.

https://digitalcommons.unl.edu/entomologyfacpub/94

This Article is brought to you for free and open access by the Entomology, Department of at DigitalCommons@University of Nebraska - Lincoln. It has been accepted for inclusion in Faculty Publications: Department of Entomology by an authorized administrator of DigitalCommons@University of Nebraska - Lincoln. 


\title{
Dispersal, Flight, and Diurnal Activity Patterns of Adult Southern Corn Billbugs (Coleoptera: Curculionidae) ${ }^{1,2}$
}

\author{
R. J. WRIGHT, ${ }^{3}$ J. W. VAN DUYN, AND J. R. BRADLEY, JR. \\ Department of Entomology, North Carolina State University, Raleigh, North Carolina 27650
}

\begin{abstract}
Ann. Entomol. Soc. Am. 76: 572-581 (1983)
ABSTRACT Dispersal into cornfields, flight, and diurnal activity patterns of the adult southern corn billbug (SCB), Sphenophorus callosus (Olivier), were studied in eastern North Carolina during 1979 and 1980. Corn plant damage (an index of SCB density) in fields with different cropping histories was initially concentrated either on the field edge next to last year's com in rotated fields, or the edge next to the overwintering site in nonrotated fields. Although damage patterns and trapping studies suggested that SCB dispersal into fields was primarily by walking, SCB are capable of strong flight. Weevils of both the overwintered and summer generations were caught in flight traps. Diurnal activity patterns of adult SCB were often bimodal; peak numbers of adults were found on plants and caught in pitfall traps in late morning and mid- to late afternoon. Changes in adult activity appeared to be better explained by changes in temperature than by changes in light intensity. Least activity occurred when temperatures were above $30^{\circ} \mathrm{C}$ or below $20^{\circ} \mathrm{C}$.
\end{abstract}

The southern corn billbug (SCB), Sphenophorus callosus (Olivier), is a weevil pest of com, primarily in the coastal plain region of North Carolina, South Carolina, and Georgia. Adults can severely damage or kill young corn plants by feeding at the base of the stalk (Webster 1912, Metcalf 1917, Durant 1981, 1982, Wright et al. 1982a). However, little biological research has been done on this species since the work of Metcalf (1917) in North Carolina.

Crop rotation has been suggested as a control measure for many years, because SCB have a restricted host range in Graminae, Cyperaceae, and Juncaceae (Webster 1912, Metcalf 1917, Satterthwait 1931, Wright et al. 1982b) and most dispersal appears to be by walking (Webster 1912, Metcalf 1917).

Dispersal is an important aspect of an insect's biology and is important to the use of crop rotation. Weevils of the genus Sphenophorus Schoenherr have been reported to be either weak flyers or nonflyers (Webster 1912, Metcalf 1917, Cartwright 1929, Kirk 1957, Kamm 1969, Tashiro and Personius 1970). There are no published accounts of flight for the SCB, although Metcalf (1917) speculated that flight was possible in SCB. Other aspects of dispersal in SCB are poorly understood as well.

There is some confusion in the literature about the overwintering sites of $\mathrm{SCB}$, and this has implications for the use of crop rotation. Early authors (Webster 1912, Metcalf 1917) found overwintering SCB only in the base of corn stalks in which they had developed, whereas Morgan and Beckham (1960) reported that SCB overwintered at the edges of cornfields and were never found overwintering in corn stalks.

\footnotetext{
'Sphenophorus callosus (Olivier). Voucher specimens of adults are deposited in NCSU Dept. of Entomol. collection.

${ }^{2}$ Received for publication 1 June 1982; accepted 7 March 1983 Paper no. 8049 of the journal series of the N.C. Agric. Res. Serv.,

Present address: Dept. of Entomology, Cornell University, Long Island Horticultural Research Lab, 39 Sound Avenue, Riverhead, NY
} Raleigh. 11901.
Once in cornfields in the spring, SCB move between plants, feeding and laying eggs. When not on plants, SCB may be found under soil clods, or plant debris, or they may be moving over the ground. Because of their dark coloration and slow movement, they are difficult to see when not on plants. Thus, the periodicity of their on-plant activity has implications for sampling, control with insecticides, and collecting insects for research.

Metcalf (1917) studied diurnal activity patterns of over 600 marked adult SCB by counting the numbers of SCB seen on plants and on the ground. Generally, he found that SCB had a bimodal activity pattern; the greatest numbers of SCB were seen between 0700 and $1000 \mathrm{~h}$ and 1700 and $2100 \mathrm{~h}$ (EDT). He also stated that early season activity peaked ca. $1 \mathrm{~h}$ later in the day than in mid- to late season. However, Metcalf (1917) reported his data as average values of activity during early and mid- to late season and did not record any environmental factors that might influence diurnal activity.

Our studies investigated SCB movement both between and within cornfields. Through studies of SCB dispersal and damage patterns in rotated and nonrotated cornfields, information was obtained on SCB movement in the spring from overwintering sites into cornfields. This information is useful in determining the role of dispersal in SCB biology and how best to use crop rotation as an SCB management tactic. SCB movement within cornfields was characterized in detail by studying both the on-plant and between-plant activity patterns of adult SCB and by associating changes in activity with changes in daily environmental rhythms. This information is basic to the development of SCB sampling methods and will be useful to researchers studying SCB biology and control.

\section{Materials and Methods}

\section{Dispersal into Fields}

In 1979, in Washington County, N.C., a 0.4-ha corner of a cornfield infested with SCB in 1978 was replanted with corn by using no-till techniques. The field 
corner was bordered on the $\mathrm{S}$ and $\mathrm{W}$ by woods, on the $\mathrm{N}$ by a drainage ditch and a farm road, and on the $\mathrm{E}$ by the remaining cultivated land (ca. 5 ha), which was in soybeans.

Samples were taken across the 0.4 -ha field section in a grid arrangement on three dates in May and June. The sample unit was 6.1 row-m of field corn (two 3.05-row$\mathrm{m}$ samples on adjacent rows). There were 17 total sample sites on 3 May and 57 each on the other two dates. Percentage of plants showing SCB feeding damage (Metcalf 1917, Webster 1912) was used as an index of billbug density.

Dispersal was inferred by measuring changes in the distribution of damage corresponding to the invasion of adult SCB into the field in the spring. Before billbugs became active in the spring, transects of pitfall traps (235-ml plastic cups, mouth diameter $8 \mathrm{~cm} ; 20$ traps per transect, 2 transects per field edge) were set out across the four edges of the field and into the surrounding habitats (i.e., woods on two sides, ditchbanks and uncultivated cropland) as an additional measure of dispersal. Traps were checked 1 to 2 times a week.

To monitor the occurrence of flight into or from the field, eight plywood boards ( 60 by $60 \mathrm{~cm}$ ) coated with Stickem Special on one side were placed at the edge of the field, with the bottom edge $60 \mathrm{~cm}$ above ground. Sticky traps were placed at this height because other Sphenophorus spp. in which flight has been reported fly at relatively low heights $(45$ to $90 \mathrm{~cm}$ ) (Kamm 1969, Tashiro and Personius 1970). There were two boards on each side of the field; one faced toward and one faced away from the field.

In 1980, the whole field described above was tilled and planted with corn. After planting, at the border of 1979 corn and soybeans, a fence $30 \mathrm{~cm}$ high was constructed with fiber glass sheeting to discourage SCB from walking out of the 0.4-ha corner of the field and into the adjacent commercial cornfield.

This field corner was sampled on 28 May 1980, using an SCB damage rating scale of $0=$ no damage, $1=$ leaf hole damage only, 2 = deformed growth or suckering, and $3=$ dead terminal growth. ${ }^{4}$ Samples were taken across the field in a grid arrangement as in 1979. At each sample site (50 total), two 25-consecutive-plant samples on adjacent rows were rated by the preceding damage scale. A mean damage rating was computed for each sample site.

In Tyrrell County, N.C., during May and June 1980, samples were taken in a grid pattern across two commercial comfields near two other cornfields infested with SCB in 1979. There were 45 sample sites at one field and 56 sample sites at the other. At each sample site, two 25-consecutive-plant samples on adjacent rows were rated by the preceding damage scale. Each field was

\footnotetext{
${ }^{4}$ The rating scale was designed to classify SCB damage in terms of probable severity of effect on corn yield. Equal intervals between rating values do not necessarily refiect equal intervals in SCB density. Damage to corn is related to SCB density, but it is also influenced by corn growth stage (Durant 1981, 1982, Wright et al. 1982a). Therefore, this scale is best correlated with SCB density when comparing sites or fields of equivalent growth stages.
}

composed of two sections, each ca. 40 rows wide and $0.8 \mathrm{~km}$ long with a windrow (composed of wood debris left over from land clearing (Lilly 1981), ca. 10 to 15 rows wide and running the length of the field) in between the two sections. The fields were surrounded on three sides by drainage ditches or large drainage canals, and by a dirt farm road on the fourth.

\section{Flight Studies}

Preliminary observations on SCB flight were made at the Tidewater Research Station (TRS), Plymouth, N.C., in July and August 1979 and 1980 by placing adults on the ground in an open sandy area, between 1100 and $1500 \mathrm{~h}$ (EDT). Several trials were conducted during this period. Experimental adults were of both sexes and included overwintered adults which had begun oviposition and field-collected, postteneral summer generation adults. Trials were conducted only on clear, sunny days with light wind. Ground surface temperatures were measured in several trials and ranged from 25 to $35^{\circ} \mathrm{C}$.

Because of positive results in the preceding observations in July 1979, preliminary field trials were conducted. In late August 1979, 20 plywood sticky traps $(60$ by $60 \mathrm{~cm}$ ) were placed around three sides of a cornfield in Tyrrell County, N.C., known to be heavily infested with SCB. Traps were placed with the bottom edges of the boards ca. $60 \mathrm{~cm}$ above ground and facing the cornfield. Traps were unpainted, covered with Stickem Special on one side, and had a sheet metal tray at the bottom to prevent insects from falling off. Traps were checked weekly through the end of September 1979.

In 1980, a season-long study was conducted to determine the seasonal occurrence of flight and provide data on flight direction. In May 1980, omnidirectional plywood sticky flight traps were placed at two sites in Beaufort and Tyrrell Counties, N.C., adjacent to SCBinfested cornfields. This trap was similar to one shown by Southwood (see Fig. $7.10 \mathrm{~b}$ and c on p. 251 in Southwood [1978]). The trap consisted of a square base ( 90 by $90 \mathrm{~cm}$ ) with four square baffles $(60$ by $60 \mathrm{~cm}$ ) arranged perpendicularly to the base. The baffles were fixed at right angles to each other, and the baffles on each trap were oriented with one side facing toward the cornfield and one side facing away from the cornfield. Stickem Special was spread on the trap base only. Flying insects were intercepted by the baffles and directed downward to the trapping surface. Six traps $(90 \mathrm{~m}$ between traps) were placed along the edge of a cornfield at each site, with the bottom edge ca. $30 \mathrm{~cm}$ above ground, trapping from 30 to $90 \mathrm{~cm}$ above ground. Traps were checked every 1 to 2 weeks through the summer and fall of 1980, and Stickem Special was renewed as needed.

\section{Activity Patterns}

Adult SCB activity was measured throughout $24-\mathrm{h}$ periods in three ways: (1) by pitfall trapping, (2) by visual examination of corn plants for SCB presence at the base of the stalk, and (3) by measuring egg production of adults caged outdoors. These three methods mea- 
sured different SCB behaviors. SCB caught in pitfall traps reflected the interplant movement of the population, those found on corn plants represented the feeding, and ovipositional activity and the caged adults measured ovipositional activity alone.

Field studies. In 1979, at TRS, an enclosure (0.09 ha) was constructed with sheet metal sections by burying the base of the sections in the ground. A barrier at least $30 \mathrm{~cm}$ above ground prevented SCB escape by walking. Corn was planted on 3 May, and ca. 2,000 field-collected SCB were released when corn was at the six- to eight-leaf stage (Hanway 1966).

One hundred pitfall traps (235-ml plastic cups, mouth diameter, $8 \mathrm{~cm}$ ) were arranged on the tops of five rows with equal spacing between traps in a row. Each row containing traps was $45 \mathrm{~m}$ long, and two rows separated each trap row. SCB movement was estimated by counting SCB in traps at 2-h intervals. Traps did not contain a killing agent, but SCB could not climb up the steep sides. After capture, SCB were released back into the enclosure, but away from the immediate trap site.

Numbers of SCB on corn plants were counted every $2 \mathrm{~h}$. In the first trial, 12-13 June 1979, SCB per 30.5 row-m (five 6.1-row-m samples) were counted. Later trials counted SCB per 100 corn plants (five 20 -consecutive-plant samples) to minimize variation from unequal plant stands within the enclosure (mean $\pm \mathrm{SE}=29.2$ \pm 0.71 plants per 6.1 row-m, $n=10$ ).

In 1980, studies similar to those above were conducted in a commercial cornfield near Gum Neck, Tyrrell County, N.C., known to be heavily infested with SCB. The studies were conducted in the corner of the field ( 5 rows by ca. $200 \mathrm{~m}$ ) that had the highest SCB population, as evidenced by plant damage.

Fifty pitfall traps were placed on each of two alternate rows. The 100 traps were arranged in four replicates of 25 each, with at least $20 \mathrm{~m}$ separating replicates within the same row and ca. $3 \mathrm{~m}$ between traps within replicates.

All on-plant SCB counts were made from 100 plants (four 25-consecutive-plant samples) chosen from within the area of highest SCB density. On 25 June 1980, the on-plant population was sampled from corn planted by the grower in April. On 3 July SCB were sampled from young corn plants (less than six-leaf stage) planted in the row middles several weeks earlier. SCB were concentrated on the younger plants, allowing counts to be made although the overall field population was sparse.

During both years pitfall traps were checked first, which took 10 to $15 \mathrm{~min}$, then the plants were examined, which also required 10 to $15 \mathrm{~min}$. Air temperature was measured every $2 \mathrm{~h}$ at the study site in shade at $30 \mathrm{~cm}$ above ground after SCB activity data described above were collected. Weather observations (e.g., cloud cover or rain) were made during the study.

Sunrise and sunset times were recorded from Raleigh, N.C., (Wake County), ca. $180 \mathrm{~km}$ west of TRS and 220 $\mathrm{km}$ west of the Tyrrell County site. Data were also obtained from a weather station at the Peanut Belt Research
Station, Lewiston, N.C., ca. $55 \mathrm{~km}$ west of TRS and $105 \mathrm{~km}$ west of the Tyrrell County site. Data obtained were of photosynthetically active solar radiation (400 to $700 \mathrm{~nm}$, microeinsteins/sec- $\mathrm{m}^{2}$ ) and dry bulb temperature, at hourly intervals.

SCB counts from the field studies were converted to square root of $(\mathrm{X}+0.5)$ before one-way analysis of variance. Mean separation was by Duncan's multiple range test $(P=0.05)$. Data presented are based on the untransformed counts.

Cage studies. Ovipositional activity was studied separately at TRS in 1979 with SCB caged in clear plastic boxes $(30$ by 17 by $8.5 \mathrm{~cm}$ ) held outdoors in the shade under a roofed, open-walled shed. One screen-covered hole $(5 \mathrm{~cm}$ in diameter) per box was added for ventilation. Approximately 50 field-collected SCB were put in each of nine cages with sections of corn stalks provided as a food source and oviposition site. Corn stalk sections were changed every $2 \mathrm{~h}$, and the number of eggs oviposited was determined by examining com stalks and the bottoms of the cages, because some eggs were deposited loosely. Temperature readings were taken 30 $\mathrm{cm}$ above ground, in shade, at the time the stalks were changed.

Another trial of ovipositional activity was conducted at TRS in 1980. Eight female and three male SCB were put in each of $10473-\mathrm{ml}$ glass jars with wire screen tops. Jars were half buried in soil between rows in a cornfield. Sections of corn were changed every $4 \mathrm{~h}$ and examined for eggs. Temperature was recorded at that time at $30 \mathrm{~cm}$ in shade in the corn canopy. The temperature within the jars did not differ more than $0.5^{\circ} \mathrm{C}$ from air temperature in several tests.

\section{Results and Discussion}

\section{Movement into Fields}

The distribution of damage on the first sampling date, 3 May, showed a high concentration of damage on the two field edges near the woods (Fig. 1A). Percent plants with SCB damage ranged from 85 to $93 \%$ on the W side of the field (near the woods) to 6 to $8 \%$ on the NE corner of the field furthest away from both field edges bordering woods.

As sampling continued at two later dates, the gradient of damage decreased, corresponding to the invasion of SCB adults into the field. By 11 May, damage had increased to ca. $100 \%$ all along the $\mathrm{W}$ side of the field and had increased as high as 31 to $48 \%$ in the NE corner of the field (Fig. 1B). Data from 5 June are not presented, because by this time many plants on the $\mathrm{W}$ side of the field had either died or recovered, so the percentage of surviving plants damaged was reduced from ca. 100 to between 56 and 90 . However, percent damaged plants in the NE corner had increased to between 44 and 73 .

SCB were caught in pitfall traps as far as $10 \mathrm{~m}$ into the woods from the field edge in April 1979. This fact and the early-season distribution of damaged plants (Fig. I) 

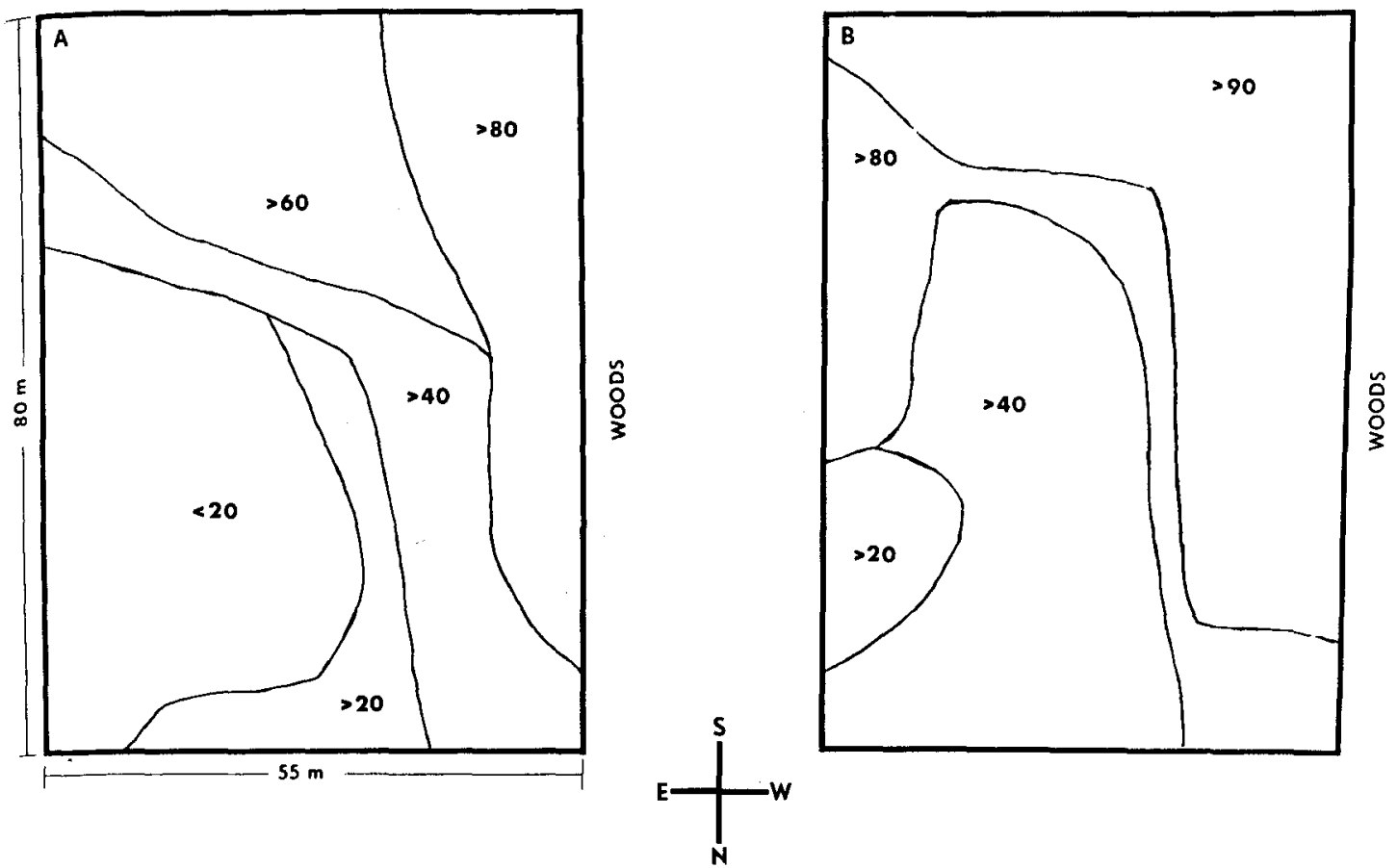

FIG. 1. Changes of distribution of damage to field corn by adult SCB, Washington County, N.C.: (A) 3 May, (B) 11 May 1979. Values of contour lines are of percent SCB-damaged corn plants.

suggest that overwintered SCB entered the field from the woods or the field edge.

Several lines of evidence suggest that SCB dispersal into this field was mostly by walking from the field edge and surrounding woods. In eastern North Carolina, SCB were observed to become active in mid-April, with the largest numbers active by the last week of April and the first week of May (Wright 1981). Yet, even in the 0.4ha field comer observed, it took well over a month for SCB to colonize the field completely. Also, no SCB were caught on the sticky boards. Although this does not prove that flight did not occur, because the number of traps was small and at only one height, the persistence of the damage gradients in the field suggests that immigration by flight was not a major source of colonizing SCB. This cornfield in 1978 was the closest source of SCB known to us in this area, and SCB damaging this field in 1979 probably were produced here in 1978.

Table 1 shows the distribution of plant damage as measured by a damage rating scale, at the Washington County field on 28 May 1980. As in 1979 at this site (Fig. 1), damage was concentrated on the $\mathrm{W}$ edge of the field, near the woods. All surrounding crop areas in 1979 were in soybean, so the only nearby source of SCB was this 0.4 -ha field corner of corn in 1979. Since the land was tilled before planting in 1980, this damage distribution (Table 1) does not rule out SCB overwintering within the field, but does show that large numbers of SCB overwintered at the field edge or in the woods. Again, the gradient of damage within a small field as late as 28 May demonstrates the low dispersal rate of SCB into and within cornfields.

The pattern of plant damage at the Tyrrell County site in 1980 (Fig. 2) in relation to possible SCB sources demonstrated that SCB damage was concentrated at the interface between the previous year's corn and the present year's corn when corn was rotated. Plant damage decreased rapidly within a field as one moved away from this interface. This again shows that SCB dispersal within a field was slow. With data from the field section directly $\mathrm{N}$ of the 1979 source of $\mathrm{SCB}$, a regression analysis of plant damage rating (y) vs. distance (m) from the front of the field $(\mathrm{X})$ was performed. It is predicted from this linear regression that zero damage occurs within $300 \mathrm{~m}(1,000 \mathrm{ft})$ of the front of the field $(\mathrm{y}=0.876-$ $0.0028 X, \mathrm{r}^{2}=0.65,29 \mathrm{df}$ ).

The least distance necessary to rotate corn away from a source of SCB is not known. Although most SCB damage occurred within $300 \mathrm{~m}$ of the field in which SCB had developed when corn was nearby (Fig. 2), it is likely that SCB would move farther if no favorable food source was found.

\section{Flight Studies}

In 1979, two Sphenophorus spp. weevils were collected on sticky boards on 12 September in Tyrrell County. One was $S$. callosus, and the other species was not identified. No more SCB were caught in traps during the remainder of September. 
Table 1. Mean SCB damage rating ${ }^{a}$ per 50 corn plants at each sample site, Washington County, N.C., 28 May $1980^{b}$

\begin{tabular}{|c|c|c|c|c|c|}
\hline \multirow{2}{*}{ Rows } & \multicolumn{5}{|c|}{ Distance from front of field $(\mathrm{m})$} \\
\hline & 12.2 & 24.4 & 36.6 & 48.8 & 61.0 \\
\hline $3-4$ & 1.26 & 1.32 & 1.68 & 1.34 & $1.28^{c}$ \\
\hline $8-9$ & 1.52 & 1.34 & 1.68 & 1.10 & $1.32^{c}$ \\
\hline $13-14$ & 1.42 & 1.34 & 1.52 & 1.52 & $1.34^{c}$ \\
\hline $18-19$ & 1.64 & 1.42 & 1.36 & 1.48 & 1.38 \\
\hline $23-24$ & 1.20 & 1.26 & 1.60 & 1.28 & $1.20^{\circ}$ \\
\hline $28-29$ & 1.16 & 1.12 & 1.16 & 0.68 & 0.98 \\
\hline $33-34$. & 0.60 & 1.18 & 0.60 & 0.36 & $0.72^{c}$ \\
\hline $38-39$ & 0.42 & 0.58 & 0.48 & 0.26 & $0.56^{c}$ \\
\hline $43-44$ & 0.34 & 0.00 & 0.48 & 0.32 & $0.58^{\mathrm{c}}$ \\
\hline $48-49$ & $0.26^{d}$ & $0.38^{d}$ & $0.34^{d}$ & $0.40^{t}$ & $0.24^{c . d}$ \\
\hline
\end{tabular}

\footnotetext{
${ }^{a}$ Damage rating scale: $0=$ no damage; $1=$ leaf hole damage only; 2 = deformed growth or suckering; $3=$ terminal growth dead.

${ }^{b}$ Increasing row number corresponds to W-E transect and increasing distance from front ( $\mathrm{N}$ side) of field corresponds to N-S transect (see Fig. 1).

'Slope from linear regression of values in this row is not significantly different from zero $(t=0.077-2.86,3$ df, $P>0.05)$. Values in rows not footnoted have slopes significantly different from zero $(t=3.21-3.44,3 \mathrm{df}, P<0.05$ ).

¿Slope from linear regression of values in this column is significantly different from zero $(t=8.9-16.3,8 \mathrm{df}, P<0.001)$.
}

In 1980, six overwintered SCB were found on the omnidirectional sticky boards during the period from 22 May to 20 June. One SCB was found on 20 August. Traps were maintained through the end of October, but no more SCB were caught.

SCB were observed to fly at TRS in 1979 and 1980; both males and females flew within 1 to 5 min of being placed on the ground on several occasions in July and August. ${ }^{5}$ Some flights were seen over the top of a nearby two-story building and were observed to continue downwind or crosswind until they were out of sight. Other SCB flew at lower altitudes and for shorter durations, similar to other Sphenophorus spp. which are known to fly (Kamm 1969, Tashiro and Personius 1970). Weevils of both the overwintered and summer generations were observed to fly. All flying weevils took off facing into the wind.

Weevils observed to fly exhibited distinct behavior before flight occurred. Nonflying individuals tended to walk away from the release site until they made contact with a plant, and then remained at the base of the plant. Individuals which flew tended to stay in the open area where they were released. They walked in tight circles, often starting and stopping abruptly. Before opening of elytra, the orientation of the body changed. The head and thorax were pulled down, and the body presented a more level appearance from a lateral view. At the time of elytral opening, all individuals were facing into the wind. The starting and stopping in circles may be associated with orientation into the wind before flight.

Our observations are the first to demonstrate strong long-range flight in SCB or any Sphenophorus spp. Other species are either nonflyers, such as $S$. maidis (Cartwright 1929, Kirk 1957), or fly one feebly-60 to $90 \mathrm{~cm}$ off

${ }^{5}$ Seven maize billbugs, $S$. maidis Chittenden (five males, two females), were tested concurrently with SCB in July 1979. Under conditions that stimulated flight in SCB, no $S$. maidis made any attempt to fly. These weevils were from a laboratory culture that was near the end of its reproductive activity at that time. Kirk (1957) reported observations of $S$. maidis attempting to fly, but none flew. the ground for short distances, such as $S$. venatus confluens Chittenden (Kamm 1969) or S. parvulus Gyllenhal (Tashiro and Personius 1970).

Although flight occurred in the field in both the overwintered and summer generation adults, the importance of flight to the population biology and management of SCB is unknown, because the proportion of the population flying and the average distance traveled are not known. Most economic infestations of SCB appeared to be localized and could be explained by close proximity to previously infested corn or nutsedge plants (e.g., Fig. 2). However, flight, even if of low frequency, may be very important in the persistence and spread of local populations. Based on the altitude attained by weevils observed to fly and the wind speed, it is estimated that flights at least $400 \mathrm{~m}$ in distance are possible for SCB. Therefore, SCB flight should be considered in the future use of crop rotation as a major component in a management program.

Although little is known about the role of migration strategies (Dingle 1972) in the life history of SCB or other Sphenophorus spp., some speculation is possible. As noted by Southwood (1962), there often is a correlation between an insect's dispersal behavior and the spatial and temporal arrangements of its hosts. Sphenophorus spp. of the United States largely develop in species of Graminae and Cyperaceae, with lesser numbers of species developing in Typhaceae, Sparganiaceae, Juncaceae, and Pontederiaceae (Satterthwait 1931, and Vaurie 1951). Many of these host species are found in marshy, low-lying areas, often in extensive, perennial "patches." To use the terminology of Feeny (1976), many are "apparent" host species, in space and time. Under these circumstances, one would predict that Sphenophorus spp. would not have evolved strong dispersal capabilities, and the evidence discussed previously suggested that they have not. Of those species studied to date, only $S$. parvulus, $S$. venatus confluens, and $S$. callosus have been reported to fly (Tashiro and 


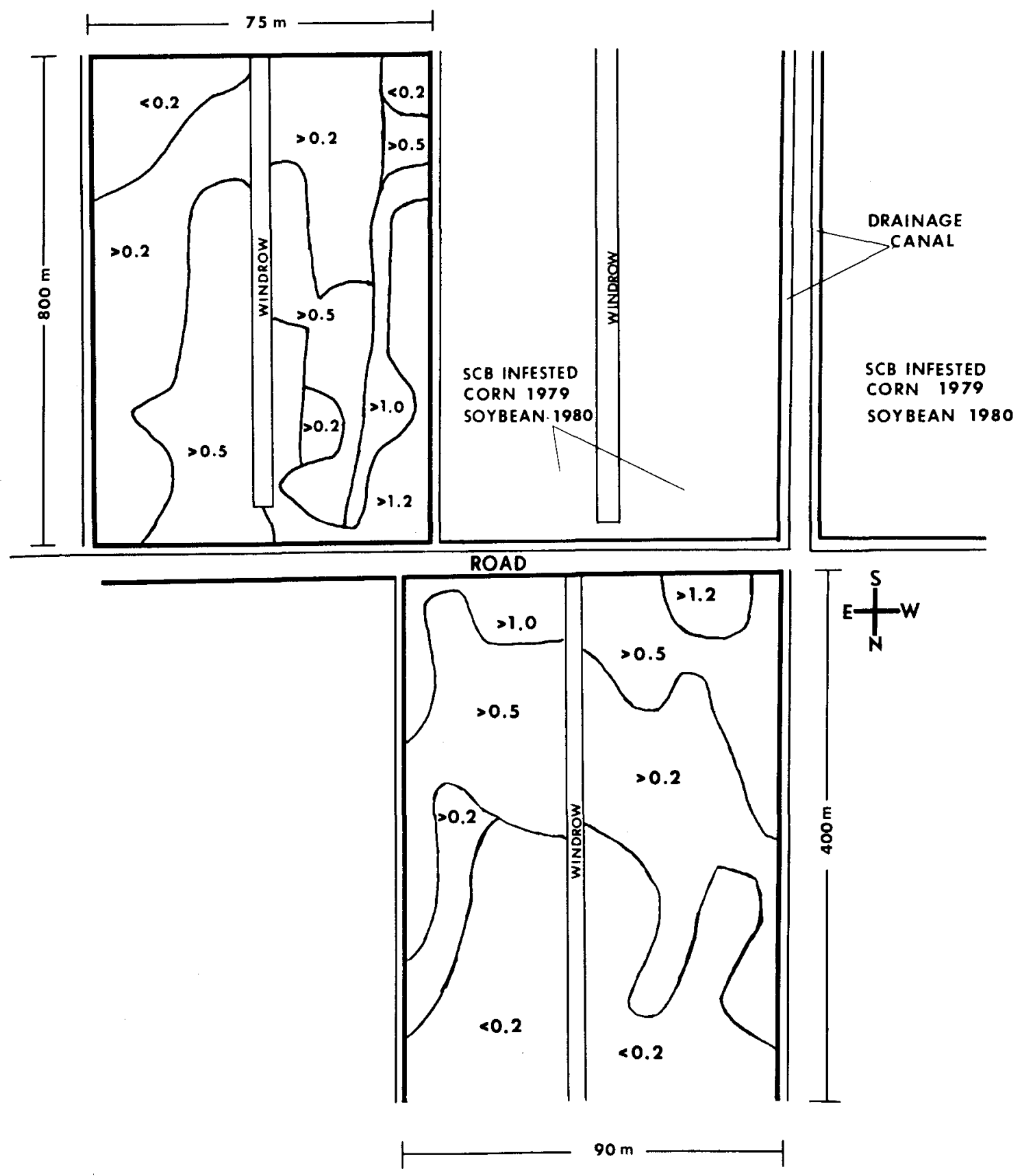

FIG. 2. Distribution of damage to field corn by adult SCB, Tyrrell County, N.C., 1980. Contour lines are of average damage ratings (see text for explanation of damage rating scale). Field dimensions are not drawn to scale. 1980 corn was either in nonSCB host plant crops in 1979 or was not previously cultivated.

Personius 1970, Kamm 1969, Wright 1981), and only $S$. callosus flies strongly. It is interesting to note that, of these three species, $S$. callosus is the only one primarily dependent on an annual crop host plant which is often rotated. This represents a relatively ephemeral host environment compared with that of other Sphenophorus spp.

\section{Activity Patterns}

In general, SCB activity patterns observed in the field corresponded to the bimodal pattern described by Metcalf (1917). However, our data also showed the variability in activity which appeared to be related to variable environmental factors (Tables 2 and 3 ). 
Table 2. Activity patterns of SCB adults, TRS, Plymouth, N.C., 1979

\begin{tabular}{|c|c|c|c|c|c|c|}
\hline \multirow[b]{2}{*}{ Date } & \multirow[b]{2}{*}{$\begin{array}{l}\text { Time } \\
\text { (EDT) }\end{array}$} & \multicolumn{2}{|c|}{ Mean no. of SCB sampled by: } & \multirow[b]{2}{*}{$\begin{array}{c}\text { Solar } \\
\text { radiation }\end{array}$} & \multirow[b]{2}{*}{$\begin{array}{l}\text { Dry bulb } \\
\text { temp }\left({ }^{\circ} \mathrm{C}\right)\end{array}$} & \multirow{2}{*}{$\begin{array}{c}\text { Sunrise and } \\
\text { sunset times } \\
\text { (EDT) }^{b}\end{array}$} \\
\hline & & $\begin{array}{c}\text { Pitfall } \\
\text { trap }\end{array}$ & $\begin{array}{c}\text { Plant } \\
\text { inspection }\end{array}$ & & & \\
\hline \multirow[t]{12}{*}{ 12-13 June } & 1700 & $2.0 a^{c}{ }^{c}$ & $5.0 \mathrm{a}^{r}$ & 1,018 & $24.5^{d}$ & \\
\hline & 1900 & $1.0 \mathrm{bc}$ & $1.4 \mathrm{def}$ & 199 & 20.8 & $20: 32$ \\
\hline & 2100 & $0.2 b c$ & $0.8 \mathrm{efg}$ & 0 & 18.1 & \\
\hline & 2300 & $0.0 \mathrm{c}$ & $0.0 \mathrm{~g}$ & 0 & 15.5 & \\
\hline & 0500 & $0.0 c$ & $0.0 \mathrm{~g}$ & 2 & 13.0 & $05: 58$ \\
\hline & 0700 & $0.2 b c$ & $0.4 \mathrm{fg}$ & 194 & 16.7 & \\
\hline & 0900 & $0.4 \mathrm{bc}$ & $3.4 \mathrm{abc}$ & 1,259 & 22.3 & \\
\hline & 1100 & $3.6 \mathrm{a}$ & $4.6 \mathrm{ab}$ & 1,899 & 24.5 & \\
\hline & 1300 & $1.6 \mathrm{abc}$ & $2.8 \mathrm{bcd}$ & 1,840 & 25.9 & \\
\hline & 1500 & $0.6 \mathrm{bc}$ & $1.2 \mathrm{defg}$ & 1.752 & 26.5 & \\
\hline & 1700 & $1.8 \mathrm{abc}$ & $1.6 \mathrm{cdef}$ & 914 & 25.9 & \\
\hline & 1900 & $0.8 \mathrm{bc}$ & $2.2 \mathrm{cde}$ & 233 & 22.6 & $20: 32$ \\
\hline \multirow[t]{12}{*}{ 19-20 June } & 1900 & - & 2.0abcde & 128 & $22^{e}$ & \\
\hline & 2100 & $0.2 b c$ & $0.4 \mathrm{cde}$ & 0 & 18 & $20: 34$ \\
\hline & 2300 & $0.0 \mathrm{c}$ & $0.2 \mathrm{de}$ & 0 & 17 & \\
\hline & 0500 & $0.0 \mathrm{c}$ & $0.0 \mathrm{e}$ & 3 & 12 & $05: 59$ \\
\hline & 0700 & $0.0 \mathrm{c}$ & $0.2 \mathrm{de}$ & 163 & 17 & \\
\hline & 0900 & $0.2 b c$ & $3.2 \mathrm{a}$ & 1,322 & 21 & \\
\hline & 1100 & $2.4 \mathrm{a}$ & $3.8 \mathrm{a}$ & 1,948 & 26 & \\
\hline & 1300 & $1.0 b c$ & $2.8 \mathrm{ab}$ & 1,979 & 27 & \\
\hline & 1500 & $0.4 b c$ & $2.4 \mathrm{abc}$ & 1,772 & 26 & \\
\hline & 1700 & $1.4 \mathrm{ab}$ & 2.0abcde & 1,084 & 24 & \\
\hline & 1900 & $0.6 \mathrm{bc}$ & $2.2 \mathrm{abcd}$ & 259 & 21 & \\
\hline & 2100 & $0.2 \mathrm{bc}$ & $0.8 \mathrm{bcde}$ & 0 & 14 & $20: 34$ \\
\hline \multirow[t]{8}{*}{26 June } & 0800 & - & 0.06 & 970 & 18 & $06: 00$ \\
\hline & 1000 & $0.0 \mathrm{~b}$ & $1.2 \mathrm{ab}$ & 1,362 & 23 & \\
\hline & 1200 & $0.4 \mathrm{ab}$ & $2.2 \mathrm{a}$ & 1,797 & 26 & \\
\hline & 1400 & $1.0 \mathrm{ab}$ & $1.4 \mathrm{ab}$ & 1.708 & 24 & \\
\hline & 1600 & $0.0 \mathrm{~b}$ & $1.8 \mathrm{ab}$ & 1.306 & 25 & \\
\hline & 1800 & $1.2 \mathrm{a}$ & $0.4 a b$ & 691 & 22 & \\
\hline & 2000 & $0.4 a b$ & $0.0 \mathrm{~b}$ & 20 & 18 & $20: 35$ \\
\hline & 2200 & $0.0 \mathrm{~b}$ & - & 0 & 15 & \\
\hline
\end{tabular}

${ }^{a}$ Radiation measured as microeinsteins $/ \mathrm{sec}-\mathrm{m}^{2}$ at 400 to $700 \mathrm{~nm}$, from Peanut Belt Research Station, Lewiston, N.C.

bSunrise and sunset times from Raleigh, N.C.

'Means followed by the same letter within a column for each trial are not significantly different at 0.05 level, by Duncan's multiple range test. ${ }^{d}$ Dry bulb temperatures from Peanut Belt Research Station, Lewiston, N.C. Dry bulb temperatures from Tidewater Research Station, Plymouth, N.C. 12 June, maximum $25.6^{\circ} \mathrm{C}$, minimum $9.4^{\circ} \mathrm{C}, 5 \mathrm{p} . \mathrm{m} .23 .9^{\circ} \mathrm{C} ; 13 \mathrm{June}$, maximum $27.8^{\circ} \mathrm{C}$, minimum $12.2^{\circ} \mathrm{C}, 5 \mathrm{p} . \mathrm{m} .25 .0^{\circ} \mathrm{C}$.

Dry bulb temperature from experimental site, in shade, TRS, Plymouth, N.C.

On 12 and 13 June 1979 (Table 2), numbers of onplant SCB were highest from 0900 to 1300 (EDT). At 1500 , on-plant counts were significantly lower than at 0900 to $1100 \mathrm{~h}$. This midday depression was associated with the peak temperature for the day, whereas light intensity peaked at $1100 \mathrm{~h}$. On-plant activity was lowest when temperatures were below $20^{\circ} \mathrm{C}$, and it did not appear to be influenced by low light intensity if temperatures were above $20^{\circ} \mathrm{C}$. For example, comparing 0700 and $1900 \mathrm{~h}$, there were significant differences in on-plant SCB counts, little difference in light intensity (194 vs. 233 microeinsteins/sec-m ${ }^{2}$ ), respectively, but temperatures were 16.7 and $22.6^{\circ} \mathrm{C}$, respectively.

On 19 and 20 June 1979, there were no significant changes in on-plant SCB counts from 0900 to $1900 \mathrm{~h}$ (Table 2). This corresponded to the period of time when temperatures were above $20^{\circ} \mathrm{C}$. Light intensity varied from 259 to 1,948 microeinsteins/sec-m ${ }^{2}$ during this period.
The results of field studies in 1980 were similar to 1979. However, numbers of SCB caught in pitfall traps were low, with no significant differences on either study date with respect to time of day (Table 3). On 3 July there were two peak on-plant activity periods, with a midday depression of on-plant activity at $1500 \mathrm{~h}$ corresponding to the occurrence of peak temperatures, whereas light intensity peaked at $1100 \mathrm{~h}$ (Table 3 ). Also, SCB activity was high at 0600 and 1700 to $1900 \mathrm{~h}$, during low light intensity, whereas temperatures were above $20^{\circ} \mathrm{C}$.

On 25 June 1980 (Table 3), it was cloudy during most of the study period and rained intermittently. The onplant SCB population was high at the first sample time $(0600 \mathrm{~h})$ and did not decrease significantly until 1700 h. Temperatures were rather constant and favorable (20 to $23^{\circ} \mathrm{C}$ ) during the study period $(0600$ to $1900 \mathrm{~h})$, yet activity was depressed toward the end of the day (after $1500 \mathrm{~h}$ ). This suggested that, when temperatures were 
Table 3. Activity patterns of SCB adults, Tyrrell County, near Gum Neck, N.C., 1980

\begin{tabular}{|c|c|c|c|c|c|c|}
\hline \multirow[b]{2}{*}{ Date } & \multirow{2}{*}{$\begin{array}{c}\text { Time } \\
\text { (EDT) }\end{array}$} & \multicolumn{2}{|c|}{ Mean no. of SCB sampled by: } & \multirow[b]{2}{*}{$\begin{array}{c}\text { Solar } \\
\text { radiation }^{a}\end{array}$} & \multirow{2}{*}{$\begin{array}{l}\text { Dry bulb } \\
\text { temp: } \\
\left({ }^{\circ} \mathrm{C}\right)^{b}\end{array}$} & \multirow{2}{*}{$\begin{array}{l}\text { Sunrise and } \\
\text { sunset times } \\
(\text { EDT) }\end{array}$} \\
\hline & & $\begin{array}{c}\text { Pitfall } \\
\text { trap }\end{array}$ & $\begin{array}{c}\text { Plant } \\
\text { inspection }\end{array}$ & & & \\
\hline \multirow[t]{7}{*}{25 June } & $0600^{d}$ & - & $2.00 \mathrm{a}^{e}$ & 54 & 20 & $06: 00$ \\
\hline & 0800 & $0.25 \mathrm{a}^{e}$ & $1.75 a b$ & 280 & 23 & \\
\hline & 1000 & $0.0 \mathrm{a}$ & $2.00 \mathrm{a}$ & 459 & 23 & \\
\hline & 1300 & $0.0 \mathrm{a}$ & $1.50 \mathrm{ab}$ & 314 & 22 & \\
\hline & 1500 & $0.25 \mathrm{a}$ & $1.25 \mathrm{abc}$ & 336 & 22 & \\
\hline & 1700 & $0.0 \mathrm{a}$ & $0.50 \mathrm{bc}$ & 136 & 21 & \\
\hline & 1900 & $0.0 \mathrm{a}$ & $0.0 \mathrm{c}$ & 37 & 22 & $20: 35$ \\
\hline \multirow[t]{8}{*}{3 July } & 0600 & - & $1.0 \mathrm{bc}$ & 40 & 23 & 06:03 \\
\hline & 0800 & $0.25 \mathrm{a}$ & $2.8 \mathrm{a}-\mathrm{c}$ & 482 & 26 & \\
\hline & 1000 & $0.25 \mathrm{a}$ & $4.2 \mathrm{a}$ & 1,356 & 29 & \\
\hline & 1100 & $0.50 \mathrm{a}$ & $3.6 \mathrm{ab}$ & 1,429 & 31 & \\
\hline & 1300 & $0.25 \mathrm{a}$ & $1.2 \mathrm{abc}$ & 1,310 & 34 & \\
\hline & 1500 & $0.0 \mathrm{a}$ & $0.6 \mathrm{c}$ & 298 & 35 & \\
\hline & 1700 & $0.25 \mathrm{a}$ & $3.0 \mathrm{ab}$ & 241 & 29 & \\
\hline & 1900 & $0.0 \mathrm{a}$ & $2.8 \mathrm{abc}$ & 195 & 28 & $20: 35$ \\
\hline
\end{tabular}

${ }^{a}$ Radiation measured as microeinsteins $/ \mathrm{sec}-\mathrm{m}^{2}$, at 400 to $700 \mathrm{~nm}$, from Peanut Belt Research Station, Lewiston, N.C.

DDry bulb temperature from experimental site, in shade.

'Sunrise and sunset times from Raleigh, N.C.

¿Generally cloudy all day.

'Means followed by the same letter within a column for each trial are not significantly different at the 0.05 level, by Duncan's multiple range test.

50600 to $1000 \mathrm{~h}$, partly cloudy; 1000 to $1500 \mathrm{~h}$, clear; 1500 to $1900 \mathrm{~h}$, partly cloudy.

Table 4. Ovipositional patterns of ca. 450 SCB adults caged outdoors, TRS, Plymouth, N.C., 1979

\begin{tabular}{|c|c|c|c|c|c|}
\hline Date & $\begin{array}{l}\text { Time } \\
\text { of day } \\
\text { (EDT) }\end{array}$ & $\begin{array}{c}\text { No. of SCB } \\
\text { eggs laid }\end{array}$ & $\begin{array}{l}\text { Dry bulb } \\
\text { temp } \\
\left({ }^{\circ} \mathrm{C}\right)^{a}\end{array}$ & $\begin{array}{l}\text { Solar } \\
\text { radiation }\end{array}$ & $\begin{array}{c}\text { Sunrise and } \\
\text { sunset times } \\
(E D T)^{r}\end{array}$ \\
\hline \multirow[t]{2}{*}{3 July } & 2100 & - & 23 & 0 & $20: 35$ \\
\hline & 2300 & $11^{d}$ & 20 & 0 & \\
\hline \multirow[t]{12}{*}{4 July } & 0100 & 8 & 20 & 0 & \\
\hline & 0300 & 7 & 19 & 0 & \\
\hline & 0500 & 6 & 19 & 1 & \\
\hline & 0700 & 6 & 20 & 73 & $06: 04$ \\
\hline & 0900 & 4 & 24 & 569 & \\
\hline & 1100 & 13 & 28 & 1,076 & \\
\hline & 1300 & 15 & 30 & 1,115 & \\
\hline & 1500 & 27 & 31 & 1.023 & \\
\hline & 1700 & 21 & 28 & 328 & \\
\hline & 1900 & 24 & 26 & 261 & \\
\hline & 2100 & 24 & 23 & 7 & $20: 35$ \\
\hline & 2300 & 27 & 23 & 0 & \\
\hline \multirow[t]{11}{*}{5 July } & 0100 & 36 & 21 & 0 & \\
\hline & 0300 & 6 & 19 & 0 & \\
\hline & 0500 & 9 & 18 & 0 & \\
\hline & 0700 & 1 & 17 & 69 & $06: 04$ \\
\hline & 0900 & 0 & 19 & 689 & \\
\hline & 1100 & 4 & 22 & 1,599 & \\
\hline & 1300 & 6 & 24 & 2,024 & \\
\hline & 1500 & 19 & 26 & 1,662 & \\
\hline & 1700 & 10 & 25 & 65 & \\
\hline & 1900 & 14 & 25 & 0 & \\
\hline & 2100 & 10 & 19 & 0 & $20: 35$ \\
\hline
\end{tabular}

"Dry bulb temperature from experimental site, in shade, $30 \mathrm{~cm}$ above ground.

${ }^{b}$ Radiation measured as microeinsteins $/ \mathrm{sec}-\mathrm{m}^{2}$, at 400 to $700 \mathrm{~nm}$, from Peanut Belt Research Station, Lewiston, N.C.

'Sunrise and sunset times from Raleigh, N.C.

${ }^{d}$ Significant deviation from a uniform distribution $\left(\chi^{2}=114.2,23 \mathrm{df}, P<0.005\right)$. Egg totals refer to 2 -h period ending on indicated time of day. 
constant and favorable, some other factor(s) influenced SCB activity.

The cage study of SCB oviposition in 1979 (Table 4) was done later in the year than the field studies, and temperatures were higher. Ovipositional activity continued well after dark and peaked at $2400 \mathrm{~h}$. However, oviposition dropped off sharply as temperatures dropped below $20^{\circ} \mathrm{C}$. This is further evidence that temperature is more important in determining adult SCB behavior than light intensity. A chi-square analysis of egg totals of each 2-h period showed with high significance that egg totals were not evenly distributed throughout the period of the study ( $\left.\chi^{2}=11.2,23 \mathrm{df}, P<0.005\right)$.

In this experiment, temperatures as high as $31^{\circ} \mathrm{C}$ occurred without any depression in ovipositional activity. In the field studies, temperatures this high resulted in decreased on-plant activity (Table 3 ). It is possible that SCB in the field buried themselves completely below ground and continued feeding and ovipositing during periods of high temperature. If so, they would have been poorly sampled by the visual examination methods used. Alternately, the environment in the cage may have been improved with respect to some factor (such as relative humidity or light intensity), allowing oviposition to continue despite the high temperatures.

The 1980 oviposition study was conducted in late July. There was no significant effect due to time to day $(\mathrm{F}=$ $0.84,1 / 6 \mathrm{df}, P>0.5$ ). Oviposition continued throughout the night, with a low of $21^{\circ} \mathrm{C}$ recorded. Again, when temperatures were favorable, light intensity did not appear to influence ovipositional activity.

Metcalf (1917) suggested that there was a difference between activity periods from early to late season, with activity peaking about $1 \mathrm{~h}$ later in the day in early season. Also, he found that the ranges between the maxima and minima of activity were greater in late season. Our results tended to confirm the seasonal differences in timing of SCB activity peaks reported by Metcalf (1917). In 1979, the June field studies (Table 2) showed a numerical peak of activity in both pitfall trapping and onplant density at ca. $1100 \mathrm{~h}$, whereas the early July 1980 field study (Table 3) showed a numerical peak of activity at $1000 \mathrm{~h}$. This difference may have been due to high inhibitory temperatures occurring earlier in the day as the summer progressed. However, our data did not provide evidence of an increase in the range later in the season.

Our studies were conducted in the later half (June and July) of the period of SCB adult activity (Wright 1981). In May, typical temperatures at TRS were: mean daily maximum, $27.0^{\circ} \mathrm{C}$, with 3 days having a maximum $\geqslant 32.2^{\circ} \mathrm{C}$ and no days with a minimum $\leqslant 0^{\circ} \mathrm{C}$ (Hardy et al. 1967). Based on our data from early June 1979 , with temperatures similar to average May conditions (Table 2), SCB adults in May will be least active during daylight hours from 1500 to $1900 \mathrm{~h}$ (EDT), or when temperatures are below $20^{\circ} \mathrm{C}$.

The conclusions of this study are based on the coincidence of SCB activity patterns with changes in temperature. It is possible that environmental characteristics not measured in this study, but correlated with temper- ature, are the actual causal factors regulating SCB activity. Laboratory studies under controlled conditions are needed to unambiguously determine the factor(s) regulating SCB activity patterns. Also, SCB were not sexed when they were counted in the field. It is not known whether there are differences between sexes in SCB diurnal behavior.

\section{Acknowledgment}

We thank G. G. Kennedy, F. Gould, G. C. Rock, and M. G. Villani for review of the manuscript, M. Rogerson, N. Whitehurst, and V. W. Modlin for technical assistance, and T. N. Hunt for advice and assistance in the planning and execution of the damage surveys. We are grateful for partial financial support received from the Corn Producers Association of North Carolina and the National Crop Loss Design Committee, USDA-SEA.

\section{REFERENCES CITED}

Cartwright, O. L. 1929. The maize billbug in South Carolina. S.C. Agric. Exp. Stn. Bull. 257. 35 pp.

Dingle, H. 1972. Migration strategies of insects. Science 175: 1327-1335.

Durant, J. A. 1981. Southern corn billbug: effect of plant height and billbug population density on injury to corn. $\mathbf{J}$. Ga. Entomol. Soc. 16: 475-478.

1982. Influence of southern com billbug (Coleoptera: Curculionidae) population density and plant growth stage infested on injury to corn. J. Econ. Entomol. 75: 892-894.

Feeny, P. 1976. "Plant apparency and chemical defense," pp. 1-40. In J. W. Wallace and R. L. Mansell [eds.], Recent advances in phytochemistry. Vol. 10. Plenum Press, New York.

Hanway, J. J. 1966. How a corn plant develops. Iowa State Univ. Coop. Ext. Serv. Spec. Rep. 48. 17 pp.

Hardy, A. F., C. B. Carney, and H. V. Marshall, Jr. 1967. Climate of North Carolina research stations. N.C. Agric. Exp. Stn. Bull. 433.75 pp.

Kamm, J. A. 1969. Biology of the billbug, Sphenophorus venatus confluens, a new pest of orchard grass. J. Econ. Entomol. 62: 808-812.

Kirk, V. M. 1957. Maize billbug control in South Carolina. S.C. Agric. Exp. Stn. Bull. 452.29 pp.

Lilly, J. P. 1981. The Blackland soils of North Carolina: their characteristics and management for agriculture. N.C. Agric. Res. Serv. Tech. Bull. 270.70 pp.

Metcalf, Z. P. 1917. Biological investigation of Sphenophorus callosus Olivier [sic]. N.C. Agric. Exp. Stn. Tech. Bull. 13. $123 \mathrm{pp}$.

Morgan, L. W., and C. W. Beckham. 1960. Investigations on control of the southern corn billbug. Ga. Agric. Exp. Stn. Mim. Ser. (N.S.) 93.9 pp.

Satterthwait, A. F. 1931. Key to known pupae of the genus Calendra, with host-plant and distribution notes. Ann. Entomol. Soc. Am. 24: 143-172.

Southwood, T. R. E. 1962. Migration of terrestrial arthropods in relation to habitat. Biol. Rev. 37: 171-214.

1978. Ecological methods with particular reference to the study of insect populations, 2nd ed. Chapman and Hall, New York, $524 \mathrm{pp}$.

Tashiro, H., and K. E. Personius. 1970. Current status of the bluegrass billbug and its control in western New York home lawns. J. Econ. Entomol. 63: 23-29.

Vaurie, P. 1951. Revision of the genus Calendra (formerly Sphenophorus) in the United States and Mexico (Coleop- 
tera: Curculionidae). Bull. Am. Mus. Nat. Hist. 98: 29186.

Webster, F. M. 1912. The so-called "curlew bug." U.S. Dep. Agric. Bur. Entomol. Bull. 95. part IV. pp. 53-71.

Wright, R. J. 1981. The biology and ecology of the southern corn billbug in eastern North Carolina. Ph.D. thesis, North Carolina State University, Raleigh. 117 pp.
Wright, R. J., J. W. Van Duyn, and J. R. Bradley, Jr. 1982a. Damage potential of adult and larval southem com billbugs (Coleoptera: Curculionidae) on field com in eastern North Carolina. J. Econ. Entomol. 75: 872-876.

1982b. Host range of southern corn billbug (Coleoptera: Curculionidae) adults and larvae. Environ. Entomol. 11: 954 957. 